\title{
RELATIONSHIP BETWEEN SPEED WITH DRIBBLING SKILLS ON THE STUDENTS OF PHYSICAL EDUCATION DEPARTMENT IN PLAYING FOOTBALL AT UNIVERSITAS MUSAMUS
}

\author{
Dilli Dwi Kuswoyo \\ Department of Physical Education, Health and Recreattion, \\ Faculty of Teacher Training and Education, Universitas Musamus, Merauke, Indonesia \\ Philipus Betaubun \\ Civil Engineering Department, Faculty of Engineering, \\ Universitas Musamus, Merauke, Indonesia
}

\begin{abstract}
The problems of this study: whether there is a relationship between speeds with dribbling skills on the students of physical education department, Universitas Musamus in playing football. The purpose of this study was to determine the relationship between speed and dribbling skills on the students of physical education department. This study was used 102 students as population with a sample of 25 students. This study is a survey method which utilizes test and measurement techniques. Correlation analysis results obtained are $r$ count 0.975>r table 0.396. This research shows that there is a very significant relationship between speed and dribbling skills on the students of physical education department, Universitas Musamus in playing football.
\end{abstract}

Keywords: speed, skill, dribbling.

Cite this Article: Dilli Dwi Kuswoyo and Philipus Betaubun, Relationship between Speed with Dribbling Skills on the Students of Physical Education Department in Playing Football at Universitas Musamus, International Journal of Advanced Research in Engineering and Technology (IJARET), 10 (6), 2019, pp 49-52.

http://iaeme.com/Home/issue/IJARET?Volume $=10 \&$ Issue $=6$

\section{INTRODUCTION}

The department of physical education which is held by Universitas Musamus studies various sports, and football is one them. There are basic techniques that must be mastered in playing football, such as; 1) Shooting techniques, 2) Passing techniques, 3) Heading techniques, 4) Controlling techniques, and 5) Dribbling techniques. Dribbling is a technique used by a player when bringing the ball toward the opponent's goal. (Kuswoyo, 2018). In addition, good and 
maximum dribbling should be achieved through excellent physical condition (speed and agility).

The purpose of this study was to determine the relationship between speed and dribbling skills in playing football on the students of physical education department, Universitas Musamus.

\section{METHODOLOGY}

This study has an experimental research through quantitative approach. In order to get results, quantitative research is relating to the variables which quantified and analyzed. Answering questions, it is using specific statistical techniques which utilizes and analysis of numerical data (Apuke, 2017; Mangkoedihardjo, 2006, 2010; Waremra and Betaubun, 2018; Pratama et al., 2019).

\subsection{Population}

The population of this study is the students of physical education department, Universitas Musamus totally 102 students which is consist of $1^{\text {st }}$ and $3^{\text {rd }}$ semesters.

It can be seen in table 1 as follows:

Table 1. Research population

\begin{tabular}{|c|c|c|}
\hline \\
\hline No & Semester/Class & Students (male) \\
\hline 1. & $1 / \mathrm{A}$ & 22 \\
\hline 2. & $1 / \mathrm{B}$ & 20 \\
\hline 3. & $1 / \mathrm{C}$ & 22 \\
\hline 4. & $3 / \mathrm{A}$ & 20 \\
\hline 5. & $3 / \mathrm{B}$ & 18 \\
\hline \multicolumn{2}{|r|}{ Total } & 102 \\
\hline
\end{tabular}

\subsection{Sample}

Sample has a rule to present the data of the study and there were $25 \%$ of students population as sample. Suharsimi (2010) stated that if the subject is less than 100 people should all be taken, if the subject is large or more than 100 people can be taken $10-15 \%$ or $20-25 \%$ or more as the repesentative can be seen in Table 2 below.

Table 2. Research sample

\begin{tabular}{|c|c|c|c|c|}
\hline No & Semester/Class & Population & \multirow{2}{*}{ Sample } & Research sample \\
& & & & \\
\hline 1. & $1 / \mathrm{A}$ & 22 & & 5 \\
\hline 2. & $1 / \mathrm{B}$ & 20 & \multirow{2}{*}{$25 \%$} & 5 \\
\hline 3. & $1 / \mathrm{C}$ & 22 & & 5 \\
\hline 4. & $3 / \mathrm{D}$ & 20 & & 5 \\
\hline 5. & $3 / \mathrm{E}$ & 20 & & Students \\
\hline \multicolumn{2}{|c|}{} \\
\cline { 1 - 2 }
\end{tabular}

\subsection{Data Analysis}

Data were collected at each stage of this study were obtained in the form of quantitative data. Then the data is analyzed quantitatively to determine the tendency of the data regarding the relationship of the treatment of the sample. By utilizing the product moment correlation formula, it can be formulated as follows: 
Relationship between Speed with Dribbling Skills on the Students of Physical Education Department in Playing Football at Universitas Musamus

$$
r_{x y}=\frac{n \sum x y-\left(\sum x\right)\left(\sum y\right)}{\sqrt{\llbracket n\left(\sum x^{2}\right)-\left(\sum x\right)^{2} \rrbracket \llbracket\left(n \sum y^{2}\right)-\left(\sum y\right)^{2} \rrbracket}}
$$

Where:

$r_{x y}=$ The correlation coefficient between the variables $\mathrm{x}$ and $\mathrm{y}$ variables

$\sum x y=$ The number of multiplications between variables $\mathrm{x}$ and $\mathrm{y}$

$\sum x^{2} \quad=$ The number of the squares of $\mathrm{x}$ values

$\sum y^{2} \quad=$ The number of the squares of y values

$\left(\sum x\right)^{2} \quad=$ Total value of $\mathrm{x}$ squared

$\left(\sum y\right)^{2} \quad=$ Total value of y squared

\section{RESULTS AND DISCUSSION}

\subsection{Result}

The following data are the results of student speed measurements in dribbling.

Table 3. Calculation of the relationship of speed (x) with dribbling skills (y).

\begin{tabular}{|c|c|c|c|c|c|}
\hline $\mathbf{N o}$ & $\mathbf{x}$ & $\mathbf{y}$ & $\mathbf{x}^{\mathbf{2}}$ & $\mathbf{y}^{\mathbf{2}}$ & $\mathbf{x y}$ \\
\hline 1. & 6.91 & 12.03 & 47.7481 & 144.7209 & 83.1273 \\
\hline 2. & 7.18 & 14.05 & 51.5524 & 197.4025 & 100.879 \\
\hline 3. & 7.97 & 12.89 & 63.5209 & 166.1521 & 102.7333 \\
\hline 4. & 7.22 & 14.19 & 52.1284 & 201.3561 & 102.4518 \\
\hline 5. & 10.5 & 21.34 & 110.25 & 455.3956 & 224.07 \\
\hline 6. & 8 & 19 & 64 & 361 & 152 \\
\hline 7. & 7.97 & 14.1 & 63.5209 & 198.81 & 112.377 \\
\hline 8. & 7.88 & 13.03 & 62.0944 & 169.7809 & 102.6764 \\
\hline 9. & 6.44 & 11.72 & 41.4736 & 137.3584 & 75.4768 \\
\hline 10. & 7.56 & 16.47 & 57.1536 & 271.1609 & 124.5132 \\
\hline 11. & 8.59 & 17.1 & 73.7881 & 292.41 & 146.889 \\
\hline 12. & 8 & 21.9 & 64 & 479.61 & 175.2 \\
\hline 13. & 7.19 & 19.88 & 51.6961 & 395.2144 & 142.9372 \\
\hline 14. & 7.53 & 18.66 & 56.7009 & 348.1956 & 140.5098 \\
\hline 15. & 8.97 & 17.16 & 80.4609 & 294.4656 & 153.9252 \\
\hline 16. & 7.9 & 15.87 & 62.41 & 251.8569 & 125.373 \\
\hline 17. & 7.97 & 19.59 & 63.5209 & 383.7681 & 156.1323 \\
\hline 18. & 8.37 & 24.62 & 70.0569 & 606.1444 & 206.0694 \\
\hline 19. & 8.16 & 15.78 & 66.5856 & 249.0084 & 128.7648 \\
\hline 20. & 8.12 & 17.28 & 65.9344 & 298.5984 & 140.3136 \\
\hline 21. & 7.75 & 14.81 & 60.0625 & 219.3361 & 114.7775 \\
\hline 22. & 62.05 & 63.61 & 3850.2025 & 4046.2321 & 3947.0005 \\
\hline 23. & 58.8 & 57.77 & 3457.44 & 3337.3729 & 3396.876 \\
\hline 24. & 49.28 & 61.13 & 2428.5184 & 3736.8769 & 3012.4864 \\
\hline 25. & 58.31 & 57.37 & 3400.0561 & 3291.3169 & 3345.2447 \\
\hline Total & 394.62 & 591.35 & 14464.8756 & 20533.6441 & 16512.8042 \\
\hline
\end{tabular}

$$
\begin{array}{r}
r_{x y}=\frac{n \sum x y-\left(\sum x\right)\left(\sum y\right)}{\sqrt{\llbracket n\left(\sum x^{2}\right)-\left(\sum x\right)^{2} \rrbracket \llbracket\left(n \sum y^{2}\right)-\left(\sum y\right)^{2} \rrbracket}} \\
=\frac{412820.1-(394.62)(591.35)}{\sqrt{\llbracket 361621.89-155724.94 \rrbracket \llbracket(513341.1)-(349694.82) \rrbracket}} \\
r_{x y}=0.9776
\end{array}
$$


From the analysis of the data which using analytical techniques $r_{x y}$, it has acquired $r_{x y}$ count calculated at 0.9776 , while the value of the $\mathrm{r}$ (table) 0.396 with significance level of $5 \%$ and the value of $\mathrm{N}=25 . \mathrm{r}$ count $>\mathrm{r}$ table, it means there is a significant correlation between the speed with dribbling skills on the students of physical education department, Universitas Musamus.

\subsection{Discussion}

Based on the results of the study showed that there is a significant relationship between speed with the results of dribbling in soccer. This can be proven through the results of the analysis of correlation test data where the value of $r$ count is $0.9776>r$ table 0.396 . The research results show the speed greatly contribute positively to the player's ability to dribble.

\section{CONCLUSION}

Based on the analysis of data to answer the research hypothesis put forward the obtained value of $r$ count $r_{x y} 0.9776$ based on significance level of $5 \%$, and $\mathrm{N}=25$, with a value of $\mathrm{r}$ table 0.396 and the value of each variable consists of; $\sum x y=16512.8042, \sum x=394.62$, $\sum y=591.35, \sum x^{2}=14464.8756, \sum y^{2}=20533.6441$. Thus, the null hypothesis is rejected and the alternative hypothesis is accepted. From the explanation above, there is a significant relationship between speed and dribbling skills on the students of physical education department, Universitas Musamus in playing football.

\section{REFERENCES}

[1] D. D. Kuswoyo, Identifikasi Tingkat Keterampilan Sepak Bola Siswa, 2018

[2] Putra Kelas V SDN Monta Kecamatan Monta Kabupaten Bima Tahun Ajaran,” J. Ilmu Keolahragaan, 2018-2019, vol. 17, no. 2, pp. 6-10.

[3] O. D. Apuke, Quantitative Research Methods : A Synopsis Approach," Kuwait Chapter Arab. J. Bus. Manag. Rev., 2017, vol. 6, no. 11, pp. 40-47.

[4] S. Arikunto, Prosedur Penelitian Suatu Pendekatan Praktek. Jakarta: Rineka Cipta, 2010

[5] Faruq, M. M,Meningkatkan Kebugaran Tubuh Melalui Permainan \& Olahraga Sepakbola. Jakarta: PT. Gramedia Widiasarana Indonesia, 2008

[6] Herwin, Keterampilan Sepakbola Dasar. Yogyakarta: FIK UNY, 2004

[7] Mangkoedihardjo, S, A new approach for the Surabaya sewerage and sanitation development programme 2020. Advances in Natural and Applied Sciences 4 (3), 2010, pp 233-235.

[8] Mangkoedihardjo, S, Biodegradability improvement of industrial wastewater using hyacinth. Journal of Applied Sciences, 6(6), 2006, pp 1409-1414.

[9] Nasra Pratama, Fransiskus Xaverius Manggau, Philipus Betaubun, Attitude Quadrotor Control System with Optimization of PID Parameters Based On Fast Genetic Algorithm. International Journal of Mechanical Engineering and Technology, 10(1), 2019, pp 335343.

[10] Richard S. Waremra and Philipus Betaubun, Analysis of Electrical Properties Using the four point Probe Method. E3S Web of Conferences 73, 2018, pp 13019. 